This is an Accepted Manuscript of an article published by Taylor \& Francis in Ethnos (2016), available online: http://www.tandfonline.com/doi/full/10.1080/00141844.2015.1107604.

\title{
Introduction: Consumer and Consumed
}

James Staples and Jakob A. Klein

The papers that make up this collection were already long in development when the European 'horsemeat scandal' in early 2013 threatened to derail still further what fragile trust there remained in food producers and retailers. ${ }^{1}$ This scandal entailed the discovery that horsemeat was being passed off in branded ready-made meals and processed foods as other types of more culturally acceptable meat, beef in particular (Lawrence 2013). But earlier animal foodrelated crises - from the discovery of Bovine Spongiform Encephalopathy (BSE) in cattle in the 1980 s, to the widespread contamination of powdered milk with melamine in China that came to light in 2008 - had already made it abundantly plain that, in the context of industrialising and globalising food supply systems, the animals we eat do not simply sustain our bodies or satisfy our culinary tastes but, in doing so, come profoundly to reshape social, economic and ecological relations and cultural understandings of edibility, taste and health.

Connections between humans and animals-as-food are not simply one-way relationships between consumer and consumed, but involve a more complex set of relations concerned, among other things, with ecological change, world markets and local economic conditions, health and food safety, labour relations, and changing cultural values. For example, growing meat consumption has been described as part of a wider, increasingly globalised 'nutrition transition' away from diets rich in fibres and complex carbohydrates, a transition associated with emergent health concerns including rises in obesity, type II diabetes, gastrointestinal disorders, cardiovascular illnesses and certain cancers (Popkin 
1993; Drewnowski 1999).

Further, increases in meat consumption have been enabled by rapid expansion and intensification of animal rearing - on some estimates the number of farm animals slaughtered for human consumption each year is set to double from around 60 billion in 2010 to 120 billion by 2050 (D'Silva \& Webster 2010). The rapid growth of the livestock industry, involving various constellations of actors including state bodies, agribusinesses and smallscale farmers - has been linked with: the emission of greenhouse gases and depletion of water resources; the severe exploitation of both animals and humans; the emergence and spread of virulent bacteria such as salmonella and E. coli 0157:H7; and new animal-borne diseases from 'mad cow' disease to SARS, 'bird flu' and 'swine flu' (Nestle 2003; Fox 1997; Schlosser 2002; Striffler 2005; FAO 2006; Davis 2005; Kleinman \& Watson 2006; Leach \& Dry 2010; D’Silva \& Webster 2010; Smil 2002).

The recent work of investigative journalists and other writers including Eric Schlosser (2002), Timothy Pachirat (2011) and Jonathan Safran Foer (2009), echoing earlier influential critics such as Ruth Harrison (1964) and Upton Sinclair (1906) ,both informs and reflects a growing awareness, among consumers in the Anglophone world and more widely, about the environmental and social issues raised by the rapid expansion of the meat industries, and not least the mistreatment of animals. Such an awareness is evident in all of the chapters of this special issue. Thus, at least in some quarters, increased meat consumption has been accompanied by concerns about the ethics of eating meat. More widely, it has been accompanied by shifts in the types and cuts of meat eaten and the styles and contexts of consumption, indexing associated changes in the symbolic meanings of animal flesh (Gewertz \& Errington 2010; Horowitz 2006; Watson 2014). In short, meat, in so many ways, is not the inert or neutral object acted upon by human producers and consumers that some might have imagined it to be, but an unpredictable agent in ever more complex networks of human and non-human beings (Latour 2005). 
In this special issue we investigate the impact that industrialising and transnational modes of meat provisioning are having on social practices and cultural understandings surrounding the use of animals-as-food. In so doing, we build on well-established cultural and social anthropological approaches towards our relationships with the animals we eat. In particular, we develop a long-standing theme in anthropology concerning the ambiguities and ambivalences surrounding the consumption of animal flesh. Scholars of classification, ritual and taboo have long recognised the ambiguities inherent in meat, from Radcliffe-Brown's acknowledgment that Andamanese food taboos denoted meat as both a source of potential danger and vital sustenance (1948), to Mary Douglas's analysis of the intricate classification regulating which animals could and could not be eaten and sacrificed by the ancient Israelites according to Leviticus and Deuteronomy (1966).

The significance of meat has of course long been highlighted by anthropologists. Among social anthropologists like Radcliffe-Brown and Douglas, meat has been regarded as vital to reproducing social bodies through acts of commensality and sacrifice (see also Hubert \& Mauss 1964; Bloch 1999; Watson 2014). Cultural ecologists have highlighted its importance as a source of sustenance to the human body, providing a highly condensed supply of calories, protein and vitamins (Harris 1998a). The acquisition of animal flesh long took precedence over the gathering of plant foods in understandings of hunter-gatherer diets and social organization, and biological anthropologists built on this contested approach to argue that hunting was vital to our evolution into modern humans, an influential view that has also been challenged (for the debates, see Lee and DeVore 1968; Kelly 1995; Stanford 2001; Wrangham 2009).

To understand the significance of meat to human social life we need also to recognise the ambivalences surrounding its use. While meat may or may not be 'murder', undeniably it is a product of taking life. Watson puts it succinctly: 'meat is dead animal flesh' (2014: 25). It is the killing of other living beings that underlies much of the power and danger of animals- 
as-food, be it for humans or gods. Indeed for Veena Das, the significance of animal sacrifice has less to with mediation between humans and gods and more to do with meditation upon and enactment of the disturbing interdependence of life and death: 'sacrifice provides a dramatic expression of the ambivalence that surrounds the idea that life feeds upon life - in order to live, we must inflict some violence on the world' (Das 2013: 19).

Recognition of the physiological and other similarities between human consumers and animal consumed is crucial to understanding the emotional, ritual and moral significance of 'dead animal flesh' (Gewertz \& Errington 2010:16; Yates-Doerr \& Mol 2012; Hurn, this issue). Valeri (2000: 56) points out that virtually all taboo foods are animal in origin because, he argues, animals share many of the characteristics of agency and personhood with human beings. The danger of eating animals, as Valeri puts it, 'consists... in the conflict between their utilitarian use and their moral status' (2000: 56-57), with certain animals - those that should not usually be eaten - standing between the categories of 'man' and 'not man' (ibid: 67). Meat is desired and yet, because the animals we kill to eat also share characteristics with us - they may be afforded agency and even personhood, and are constituted as moral subjects - they also create moral problems.

How are the ambiguities of meat being affected by intensified food production and transnational food trade? To what extent are new environmental fears, health concerns and alternative food movements reshaping the boundaries between humans and the animals we eat? The relationship between consumer and consumed can no longer be explored only in relation to localised ritual practices, sacrifice, commensality and classifications, nor via comparisons between the West and the non-West (Solomon 2014: 23). Rather, we need to situate the local and the specific in the context of the transnational consumption patterns that shape and, in turn, are shaped by them. This global frame both subjects local norms to a wider moral gaze and, in some cases, leads to redefinitions of consumer-consumed relations that cannot be explained in relation to local cosmologies alone. In short, when it comes to 
understanding how humans relate to meat, we are dealing with a significantly more complex nexus of shifting relations and meanings than at any point in our history. Indeed, as recent food scandals have demonstrated, the complexity of contemporary food chains often renders the meat we consume literally ambiguous, stripped of its culturally specific referents.

This is not to say that classical anthropological notions of 'culture', including theories on classification and taboo, sacrifice and commensality, are no longer relevant to our concerns. On the contrary, a core argument in this special issue is that 'culture' remains vital to understanding the relationships between the consumer and the consumed in the contemporary world (see, especially, Holtzman in this volume). Yet recent contributions to the anthropologies of meat-eating, industrial and artisanal foods, and human-animal relations (e.g., Osella \& Osella 2008; Gewertz \& Errington 2010; Heath \& Meneley 2007, 2010; Hurn 2012: 84-97; Weiss 2011; Yates-Doerr \& Mol 2012) show us that 'culture' needs to be augmented by approaches that forefront complex ecological, political, ethical, aesthetic, sensory and social entanglements between a wide range of actors operating at a variety of scales.

Such actors are not limited to human ones. Recent debates concerning interspecies engagements and relational ontologies (Haraway 2008; Dransart 2013; Kirksey and Helmreich 2010; Hurn 2012; Abram \& Lien 2011) decentre human intention and representation to allow new perspectives on how human and non-human beings interrelate to come more sharply into focus, as Hurn emphasises in this issue. Proponents of Actor Network Theory (ANT) similarly help us to shift our gaze from a hierarchical relation between subject and object (from consumer and consumed) to a network of relations, in which the centrality of human actors is no longer taken for granted. By de-coupling intentionality from agency, ANT allows us to view both living and non-living beings as potential actors (Latour 2005). These and other 'posthumanist' (Campbell 2009; Pickering 2005) approaches help us to move beyond understandings of animals (alive or dead) and 
other non-human entities as passive symbolic (Douglas 1966) or material (Harris 1998b) resources for the reproduction of human societies.

Yet - and this is a central plank of what we are trying to do in this special issue - we must not allow posthumanist approaches to obscure the human propensity to combine and make meaning of new phenomena in patterned ways, even as these patterns may become disrupted as a result of encounters between humans and between humans and non-human entities (Sahlins 1993; Wilk 2006). In this special issue, we actively engage with the posthumanist turn. Yet we also find it useful to defend a notion of 'culture' as a means to capture the complex, partial, creative, contested yet never random ways in which people attempt to deal with the deep-seated and novel ambiguities of meat through technical, material, symbolic and ritual practices. We argue that anthropological notions of 'culture', including theories of taboo, classification, commensality and sacrifice, remain highly relevant to understanding the ambiguities surrounding the relationship between consumer and consumed in contemporary contexts, particularly when invigorated by more recent, posthumanist approaches and by approaches that (also) emphasise the material and sensory dimensions of food (Sutton 2001, 2010; Abbots \& Lavis 2013; Weiss 2011; Yates-Doerr \& Mol 2012; Paxson 2008). In the remainder of this introduction we flesh out our arguments by outlining the chapters and situating them within the burgeoning anthropological literature on food industrialisation, and offering some further reflections on the recent 'horse meat scandal'.

\section{Animals-as-Food in Globalising Food Systems}

An early attempt at analysing the effects of industrialising meat production on (Western) humans' perceptions of other species is that of Nick Fiddes. In a book published over two decades ago, Fiddes (1991) argues that in Western civilisation, particularly in recent centuries, meat has been a symbol of human domination over the natural world, and indeed 
that the prestige and 'virility' of meat derives from this domination. However, he claims, the late twentieth century witnessed a growing moral unease with meat consumption and its association with human superiority over other species. For Fiddes, this apparent cultural shift is part of a wider reaction against technological modernity, spurred on by fears of rapid environmental degradation including that associated with industrialised processes of meat production.

Fiddes' book remains important for emphasising the relationship between changing practices of food production on the one hand and changing cultures of consumption on the other; although in contrast to Fiddes' claims about a cultural shift away from meat-eating others have argued, for example, that in the United States critiques of the meat industries have not led to a decrease in the taste for meat (Horowitz 2006), even if eating meat for many Americans may increasingly be accompanied by feelings of guilt, shame and disgust over the killing of animals for human consumption (Bulliet 2005) - a contradiction relevant also to several of the ethnographic settings explored in this special issue.

The authors in this issue are indebted to Fiddes' work but go beyond it in a number of ways. First, rather than make predictive statements about broad cultural shifts, the writers here share with Wilk (2006) an ethnographic commitment to revealing and understanding the complexities and contradictions inherent in the so-called 'global food system'. While intensified systems of meat supply, marked by greater economies of scale and the lengthening of supply chains; increased dependence on science and technological inputs; and greater specialisation and separation of different farming and livestock activities, may raise similar sets of concerns for people across a wide range of settings, the ethical and other cultural changes articulated with these are not unidirectional but differ between actors and contexts, even within national boundaries.

For example, in contrast and partly in reaction to veganism and vegetarianism, yet also strongly motivated by a critique of industrial farming, the UK has in recent years 
witnessed the emergence of movements encouraging 'locally raised' meat, offal-eating and a greater familiarity with the raising, slaughtering and butchering of animals. Promoted by celebrity chefs such as Hugh Fearnley-Whittingstall and Rick Stein, and arguably embraced above all among status-seeking middle-class consumers (Strong 2006), these movements also find support in the work of ecologists arguing that livestock farming has an important role to play in a future, more sustainable agriculture (Fairlie 2010). The point here is not that veganism and vegetarianism are in decline, but that reactions to contemporary meat production are taking a variety of cultural forms. Indeed, even within relatively small geographical areas - such as the rural area in Wales where Hurn (this issue) carried out her fieldwork- values and understandings vary, as demonstrated in the stark differences between those of the ashram and the conventional farmersshe describes.

Second, changes in the meanings and practices of meat-eating are understood in terms not only of conscious human, 'cultural' reflection on the 'natural' world, but also as the often divergent and incomplete but never random outcomes of material interactions between human and non-human entities. Moving beyond the nature-culture divide inherent in symbolic approaches of scholars such as Fiddes, Hurn discusses the ways in which farmers' perceptions of 'their' animals, including decisions over whether or not to eat them, often emerged through situated, multi-species practices of production. But it is not only as living, 'sentient' beings (Hurn, this issue) that animals have the capacity to act upon humans. Like other (potential) foods, meats participate in the construction of relationships between people and between people and places (Janeja 2010), not least through their effects on human bodies, including their sensory perceptions (Sutton 2001; Sutton this issue; Weiss 2011). The various appearances, textures and mouth feels, smells, tastes, even sounds, of animal flesh, physical experiences of digestion and evacuation, and the feelings of satiety its incorporation may or may not produce, are all significant to understanding how meat shapes social relations, meanings and memories. In this special issue, for example, Staples highlights that 
to people in the South Indian Christian community he studies, the importance of eating meat on Sundays and other 'special days' related in part to the sensory satisfaction derived from the particular chewiness and flavours of meat, which were not a part of ordinary, vegetablebased meals. In a similar vein, Klein (this issue) relates how embodied experiences of meat scarcity under radical socialism continued to shape practices and meanings of meat-eating among urban Chinese, particularly among the elderly.

More than other (potential) foods, meats mediate between humans and animals, and they do so in a variety of often unpredictable ways (Yates-Doerr \& Mol 2012). Thus, the materiality of meat, which crucially involves but also extends beyond moments of ingestion, is vital when we consider the relationship between producers (both human and animal) and consumers in industrialising systems. As Horowitz (2006) argues in his history of meat in the United States, the perishability of animal flesh and the irregularity of the sizes and other properties of individual animals profoundly shapes not only the preparation and eating of meat but also the ways in which it can be processed, packaged, transported and disposed. Indeed, the perishability and other material dimensions of meat and the food businesses' problematic attempts at overcoming these by industrial means are often reflected in the concerns about food safety and taste expressed by consumers, as discussed in this collection in essays by Staples and Klein, respectively.

Third, the authors in this special issue, rather than focussing on Western or other bounded 'civilisations' or 'cultures', move across and often between conventional regional and political boundaries. This movement reflects not simply the diverse regional interests of the authors but also a shared recognition of the transnational character of contemporary systems of meat provisioning and of the circulation of meanings pertaining to animal flesh. Complex transregional and transnational networks involving, among others, grain growers and feed processors; livestock farmers, farm workers and integrators; animal scientists and breeders; refrigeration, packaging and processing technologies; and wholesale and retail 
infrastructures, began to emerge in the nineteenth century, and their expansion and integration during the post-World War II period have made possible the daily consumption of 'fresh' and processed beef, pork, chicken or fish for millions of Europeans and North Americans, among others (Goody 1982; Horowitz 2006; Striffler 2005; Freidberg 2009). These networks have in recent decades come to encompass many parts of Asia, Latin America and Africa previously perceived to be 'meat poor'. China alone now produces and consumes over 50 percent of the world's pork, and relies on soybean imports from the United States, Brazil and Argentina to feed its rapidly growing population of hogs (Schneider 2011).

To be sure, meat consumption between and within countries remains highly uneven both in terms of quantities and perceived quality of cuts consumed (Gewertz \& Errington 2010; Smil 2002). In some cases the consumption of animal foods is in fact decreasing. Holtzman (2009) describes how pastoralists and former pastoralists in Northern Kenya whose diets had previously centred on milk, meat and blood have become increasingly dependent on grains, sugars and other purchased foods as a result of 'development' initiatives. Nevertheless, the rapidly growing access to domestically produced and imported meat products for millions of Chinese, Indians and others behoves us to rethink the meanings of animals-as-food among groups once assumed to be vegetarian by default or by 'culture' (Klein 2008, this issue; Osella \& Osella 2008; Staples this issue).

Furthermore, as Hurn, Klein and, especially, Holtzman, discuss in this special issue, it is not only food supply chains that have become globalised, but also the networks of religious and other ethical ideas, images and organisations, which have come to shape people's understandings of their own and others' changing relationship to animals-as-food. As Holtzman informs us, Japanese hunters and consumers of dolphins and other cetaceans increasingly must justify their practices not only to others but to themselves on the basis of categories imposed by American animal rights' activist groups.

Thus, the authors in this special issue argue that rapidly industrialising food systems 
and the plethora of attendant socio-material changes they bring to relationships between consumers and consumed calls for an anthropology of food that cuts through distinctions routinely made between the social or symbolic and the material, or between the global and the local. It is vital that we attend both to the minutiae of everyday consumer practices and to the wider - often international - networks in which those practices are located, recognising the subtle (and not so subtle) ways the one influences the other.

\section{Meat and Culture}

Ethnographic attention to changing human entanglements with meat, we argue in this special issue, enable us to chart, and also help to explain, social, economic, political and environmental changes occurring on various scales and experienced in culturally specific contexts. The papers that follow explore these entanglements in ethnographic locations in China, India, Japan and Wales. A central theme concerns the work of 'culture' in shaping our relations with the material, emotional and sensual dimensions of animals-as-food in these various contexts. This long-standing topic in the anthropology of food, often framed in terms of debates on the relationship between edibility and cultural systems of classification (e.g., Douglas 1966; Tambiah 1969; Harris 1998b), remains highly relevant today, as has been brought out by the European horsemeat affair. It is 'culture' that, for example, makes horsemeat so repellent to a British public in ways that would be alien in, say, France. Likewise, it is 'culture' that renders eating cetaceans - from whales to dolphins - acceptable to at least some of the Japanese consumers Holtzman (this issue) describes (even, in some instances, to Buddhists who otherwise decry the killing of any animal), when to American animal rights activists it appears virtually on par with cannibalism.

At the same time, ever-changing local perceptions of meat also force us to acknowledge that 'culture' is not a fixed attribute anchored to particular places. Shifts in the meanings of chicken and beef in Hindu South Asia, for example - where it is often (but 
wrongly) assumed that the sacred status of the cow keeps it safely away from the cooking pot - reference not just Hindu practice and scripture but, as Staples's paper shows, are rooted in a nexus of nationalist politics, environmental concerns, and the logics of global capitalism. Similarly, Klein discusses how the industrialisation of pork and chicken production has given rise to a greater ambivalence towards meat, and especially pork and chicken, among urban Chinese. This has contributed to a growing interest, particularly within the emerging middle class, in Buddhist vegetarian restaurants, which in turn were articulating a critique of meat that drew on both Buddhist notions of karmic retribution, and on transnational environmentalist and animal-welfare discourses. While never uniform in the past, 'Chinese' approaches to animals-as-food are becoming increasingly complex and diverse in response to the globalisation not only of food supply chains and production methods, but also of foodand animal-related discourses and social movements.

In both India and China, as Staples and Klein discuss, growing affluence and new forms of social differentiation, methods of meat production and visions of modernity, have been implicated in the unprecedented expansion of meat-eating, but also in the emergence of ambivalences, critiques and avoidances of meat or particular animal foods, which articulate both longstanding and more recent cultural practices, ideas and divisions. Such complexities remind us, as Yates-Doerr (2012) has argued, that despite the widespread assumption that demand for meat rises 'naturally' as a result of rising incomes and population growth such demands are culturally and historically highly contingent. While nutritionists may perceive pork, chicken, beef and whale flesh as sources of protein and other nutrients, to the Chinese, Welsh, Indians, Americans and Japanese discussed in this special issue these products are anything but simply 'meat'. The various meanings attached to them and the demand for them at a given historical moment cannot be assumed.

Nevertheless, the argument that the demand for 'meat' is both natural, universal and easily comparable across contexts has underpinned attempts by modernising states and the 
food industries to justify 'cheap meat' policies and the attendant intensification of livestock farming. State, science and industry have arguably come to shape demand as much as they have responded to it: the spectacular triumph in the United States since the 1960s of chicken, a bird whose flesh many Americans had previously hardly considered 'meat' at all, is a case in point (Horowitz 2006; Striffler 2005). That said, the invention and promotion of lean pigs did not succeed in convincing post-WW II Americans that they should be eating more pork (Anderson 2009).

Changes and diversities in the meanings of and demand for meat may, in line with much anthropological thinking of recent decades, complicate notions of 'culture' as a stable and internally homogeneous system of meanings. Nevertheless, not only do food classifications still clearly matter even as they change but, as Holtzman stresses in his piece, an objectified notion of 'culture' is routinely invoked both as a justification for eating or not eating particular animals or preparations, with legal protections for 'indigenous' practices globally accepted. 'Culture', again as discussed by Holtzman, can simultaneously be used as a label with which to define 'the other' as inferior. The horsemeat scandal, for example, also enabled a cosmopolitan, educated elite - for whom horse-meat was as acceptable as any other meat - to demonstrate the relative breadth of their knowledge of cuisines beyond national borders and their culinary refinement, in contradistinction to a less sophisticated order whose tastes were seen as driven by irrational and unquestioning responses to eating animals that they had not previously encountered as meat.

The potential for gastro-snobbery in relation to horsemeat consumption, however, was tempered by the uneasy recognition of a stark gulf between the premium products enjoyed by the culinary elites - where the provenance of ingredients was more carefully monitored, and where the beef, chicken or even horse consumed were exemplars of their type - and the mass-produced, cheaper goods more likely to be eaten by the poor; goods which were not what they were advertised as being and whose provenance was unknown. In the South Indian 
context discussed in Staples' paper, people eat mass-produced chickens not because they are tastier, which most agreed they are not, but because they are cheap and offered up an option of eating meat that would otherwise not be available. Similarly, it may be asked whether British consumers ate 'value ranges' of processed foods not out of a blind belief in their quality, but because it gave them affordable and convenient access to meat. This offers a good example of the fault lines that a focus on meat, its production and its consumption, throws into such stark relief, unsettling the too readily taken-for-granted.

Such disconnects between otherwise intuitively taken positions are striking in several of the papers, and point to our desire in this special issue of capturing the tensions and contradictions of everyday life that emerge so strikingly in ethnographic explorations of human-meat relationships. Liberal Euro-American elites who instinctively may veer towards a cultural position that accepts both differing culinary tastes and the concerns of animal rights activists find themselves torn when these two beliefs prove incompatible, as they do, for example, in Japan over whaling, or in India over the rights of Christians and other oppressed groups to eat the flesh of the cow if they want to. Similarly, those who decry the horrors of industrial meat production while instinctively accepting the right of developing nations to indulge in the same desire for affordable meat as the rest of the globe, or those who try to reconcile a distrust in industrialised meat production with a patriotic desire to support their country's farmers, all find themselves in uncharted territory. Ethnographic attention to relationships between consumers and consumed bring these dilemmas into focus.

\section{Trust and Distance}

In relation to the horsemeat affair, it was not just the fact that it was horse - as a culturally unacceptable meat in Britain - rather than beef that landed up in people's frozen lasagnes and burgers that disturbed consumers. It was not even, as with other health scares, that there were reported health risks from eating horses that had not been reared for 
consumption. Arguably more importantly, consumer responses were shaped by a righteous outrage that they had been duped by the producers. Fundamentally, the viability of contemporary, globalising systems of meat provisioning hinges upon the ability of producers, retailers and regulatory agencies to construct and maintain consumers' trust in the supply chain itself. In the case of the recent European horsemeat scandal, so complex were the food chains along which components of meat products travelled between farm and plate that none of those along the chain were able to say, with any certainty, what those products might contain. Laboratory DNA testing was ultimately required to identify the provenance of the meat concerned. Given that meat, as mentioned earlier with reference to Valeri's (2000) work, is particularly sensitive to taboos - with pork rejected by Muslims and Jews alike, and beef consumption anathema to the putatively purer Hindu castes - such admissions not only destroy trust (Caplan 1997) but, for those investing in industrialising food processes, threaten markets.

But how much do consumers actually want to know about the lives and deaths of the animals they consume? Indeed in certain contexts, a lack of intimacy with animals is required in order to make them morally and cognitively edible. As Sutton picks up upon in his endnote, this speaks to the well-worn logic of kinship (and, by extension, cannibalism): Americans and others do not (or should not), as Marshall Sahlins (1976) taught us, eat those with whom they have close relations. Like dogs and cats, horses, to the British, are animals with whom people have one-to-one relationships, to be treated very differently to the more generic category of cattle. Whales and dolphins are rejected as food by Americans on the basis that, as Holtzman explains, they are seen as 'intelligent' (and, therefore, more like 'us'). Valeri $(1992 ; 2000)$ argued that among the Huaulu of Seram, Eastern Indonesia, to feed an animal was to confer it with personhood and for this reason such animals were taboo to eat. Elsewhere, too, animals that are good to eat are often those that are distanced from us: homereared chickens that can only be sold to others to eat in South India (Staples, this issue), or 
livestock so objectified by industrial farming process in the United States and Britain that we can screen out its subjective capacity to feel pain or other sensations (Pachirat 2011; cf. Hurn, this issue). In European contexts since the Middle Ages, the gradual distancing of eating meat from the visceral materiality of dead animals is central to Elias's 'civilising process' (Elias 1978; Mennell 1985); in a similar vein, Vialles (1994) argues that the removal of slaughterhouses from town centres in eighteenth- and nineteenth-century France helped move the slaughtering of animals-for-food out of sight and out of mind. Arguably, it is precisely the ability of industrialised livestock farming and slaughter to distance consumers from consumed, which may facilitate the mass consumption of meat in contemporary societies.

In other contexts, however, it is the alleged intimacy between human and animal 'coproducers' that enables some to present their animal food products as more 'ethical' than others, in contrast to the perceived (but perhaps often exaggerated, see Baker 2013) disconnection between animals and humans in industrial farming. This is evident in the passionate celebration of 'locally sourced' pigs' trotters, ears and kidneys among British celebrity chefs. Similarly, sceptics of 'industrial' meat products may be attracted to 'artisan' meat foods not only by the promise of better or more unique flavours, but also on the assumption of close connections between artisan producers, the animals they raise and the 'local places' on which they are raised and that such flavours are taken to index (Cavanaugh 2007; Weiss 2011). As Heath \& Meneley (2010) discuss in their ethnography of American foie gras producers, presenting the relationship between farmers and fowl as one of intimacy and care is crucial to the construction of their products as both ethical and artisanal, in contradistinction to the mass-produced meat associated with industrialised livestock farming. Paradoxically, then, the very distancing of animal from consumer that makes mass consumption of meat an unremarkable possibility of action also might come to destroy consumers' trust that the meat they are being sold is safe and good (ethically and aesthetically) to eat. Following Heath \& Meneley's work, we need to explore 
ethnographically how consumers, producers and activists variously negotiate this paradox, paying attention to Heath \& Meneley's insight that the divide between 'artisinal' and 'industrial' foods is not simply given in the techniques and technologies of production but contested and performed (see also Cavanaugh 2007).

Thus, managing degrees of distance and intimacy between humans and animals, consumers and producers, are central to the construction of trust within systems of meat production. Yet, just as there is no a priori link between degrees of distance and intimacy on the one hand, and edibility on the other, there is also no straightforward causal relationship between a publicised food scare and consumer rejection of the product concerned. On the one hand, close ethnographic work shows how different people can react very differently to the same kinds of information. As most of us who study how people eat as well as what they say about it are well aware, sometimes the most avid upholders of food taboos in theory are also the most readily seduced by desire for the forbidden food in practice, while one person's rejection of a particular meat during a health scare presents another's opportunity to stock up on that same meat while the prices are low. Sutton (this issue), in drawing on the subtle differences and debates over food within his own family, forces us to confront the micronuances and contradictions that inform our everyday culinary choices. For instance, such contradictions were apparent among the urban Chinese vegetarians, discussed by Klein in this issue, who had to negotiate their ethical and health-related concerns about animal flesh with the ongoing centrality of meat-eating to the reproduction of family ties and other social relations.

\section{Concluding Remarks}

The killing of non-human animals for human consumption is inherently problematic. Anthropologists have long understood this, and have explored how cultural groups, especially in small-scale settings, have sought to overcome the ambiguities of 'dead animal flesh' 
through a variety of material, classificatory and ritual practices. As we have discussed in this introduction, the intensification of meat production and consumption and the scaling up of transnational food trade have added new layers of complexity and attendant dilemmas of ethics, risk and trust to age-old ambiguities, as consumers of meat have increasingly become disconnected from the human and non-human actors, places and processes involved in food production, processing and transportation.

Yet the 'industrialising' and 'globalising' of 'food systems' refer not only to changes in modes of production, distribution, consumption and disposal (Goody 1982; Evans et al. 2013), but also to new forms of national and supranational governance and regulation, and the transnational movements of migrants, civil society organisations, corporations, images and ideas that variously influence the ways in which food is produced, exchanged, consumed and imagined (Phillips 2006; Wilk 2006). Despite undoubted concentrations of power and structured patterns of inequality within global 'food regimes' (McMichael 2009), as with other 'global flows' the various 'flows' that comprise food 'globalisation' are partly disjunctive, becoming assembled in partial and contingent, if not random, ways (Appadurai 1996; Phillips 2006). For example, transnational social movements such as Slow Food that are committed to protecting 'local' and 'artisan' foods are often reacting as much to the perceived 'homogenisation' of tastes and culinary practices through food safety standards and other forms of food governance, as they are to industrial modes of producing meats and other foods per se (Leitch 2003). Yet as Leitch shows, the rapid rise of Slow Food needs to be understood within the specific contexts of Italian and European politics and consumerism since the 1980s. Indeed, in comparison to Leitch's account of Italy, in China promises to resolve food safety issues through techno-scientific industrialisation and increased standardisation appear to be much more easily compatible with celebrations of 'nature' and ‘locality’ (Tracey 2013).

As these cases suggest, the ways in which people attempt to resolve the contradictions 
and ambiguities of contemporary food production in general and meat production in particular are highly variable. Understanding these practices and the reconfiguration of boundaries between human and non-human animals to which they may give rise will require theoretical and methodological tools that help us reveal how they emerge from particular networks of actors, both human and non-human, at scales ranging from the microscopic to the global. But they will also require a continued attention to 'culture' - both as more-or-less stable assemblages of more-or-less enduring material practices and techniques, beliefs, values, and classificatory logics, and as an abstracted, objectified site of negotiation, reflection, debate, critique, invention, commodification and identity formation. Human understandings of non-human animals emerge from particular engagements between people and animals, not least in the context of raising animals, slaughtering them, sacrificing them, buying, cooking and eating them. From this perspective, animals, alive and dead, shape our understandings of them as much as our 'cultures' do; and these understandings will be highly contingent upon the broader technological and political-economic conditions that constrain these human-animal encounters. Yet, as Carrier has discussed more broadly in an essay on people's relations with their surroundings (2004), people also make abstractions from these encounters in ways that are both shaped by and may come to shape wider, collective representations and practices involving non-human animals and their uses as food. And, in turn, these abstractions may come to shape the ways in which humans engage with animals and act upon the conditions in which the latter become food. The articles in this special issue help us understand these complex, dialectical processes in contexts of food industrialisation and globalisation, showing that these processes are neither unidirectional nor haphazard.

\section{Note}

1. This special issue began its life as a panel entitled 'Biting Back: Eating and Not Eating Meat in Industrialising Food Systems', convened by the editors for the 2011 
annual conference of the Association of Social Anthropologists (ASA) at the Lampeter Campus of the University of Wales Trinity Saint David, 13-16 September. Early versions of the individual papers by James Staples and Jakob Klein were presented at the panel; Samantha Hurn, Jon Holtzman and David Sutton were subsequently invited by the editors to contribute to the collection.

\section{References}

Abbots, Emma-Jayne \& Anna Lavis (eds). 2013. Why We Eat, How We Eat: Contemporary Encounters between Foods and Bodies. Farnham, Surrey: Ashgate.

Abram, Simone \& Marianne Elisabeth Lien. 2011. Performing Nature at World's Ends. Ethnos 76(1): 3-18.

Anderson, J.L. 2009. Lard to Lean: Making the Meat-Type Hog in Post-World War II America. In Food Chains: From Farmyard to Shopping Cart, edited by Warren Belasco \& Roger Horowitz, pp.29-46. Philadelphia: University of Pennsylvania Press.

Appadurai, Arjun. 1996. Modernity at Large: Cultural Dimensions of Globalization. Minneapolis: University of Minnesota Press.

Baker, Kim. 2013. Home and Heart, Hand and Eye: Unseen Links between Pigmen and Pigs in Industrial Farming. In Why We Eat, How We Eat: Contemporary Encounters between Foods and Bodies, edited by Emma-Jayne Abbots \& Anna Lavis, pp.53-73. Farnham, Surrey: Ashgate.

Bulliet, Richard W. 2005. Hunters, Herders, and Hamburgers: The Past and Future of Human-Animal Relations. New York: Columbia University Press.

Campbell, Ben 2009. Fields of Post-Human Kinship. In European Kinship in the Age of Biotechnology, edited by Jeanette Edwards \& Carles Salazar, pp.162-178. Oxford: Berghahn. 
Caplan, Pat. 1997. Approaches to the Study of Food, Health and Identity. In Food, Health and Identity, edited by Pat Caplan, pp.1-30. London: Routledge.

Carrier, James G. 2004. Introduction. In Confronting Environments: Local Understandings in a Globalizing World, edited by James G. Carrier, pp.1-29. Walnut Creek, CA: AltaMira Press.

Cavanaugh, Jilian R. 2007. Making Salami, Producing Bergamo: The Transformation of Value. Ethnos 72(2): 149-172.

Davis, Mike. 2005. The Monster at Our Door: The Global Threat of Avian Flu. New York and London: The New Press.

Das, Veena. 2013. Being Together with Animals: Death, Violence and Noncruelty in Hindu Imagination. In Living Beings: Perspectives on Interspecies Engagements (ASA Monographs 50), edited by Penelope Dransart, pp.17-31. London: Bloomsbury Academic.

Douglas, Mary. 1966. Purity and Danger. London: Routledge \& Kegan Paul.

Dransart, Penelope (ed.). 2013. Living Beings: Perspectives on Interspecies Engagements (ASA Monographs 50). London: Bloomsbury Academic.

Drewnowski, Adam. 1999. Fat and Sugar in the Global Diet: Dietary Diversity in the Nutrition Transition. In Food in Global History, edited by Raymond Grew, pp.194206. Boulder: Westview Press.

D’Silva, Joyce \& John Webster (eds). 2010. The Meat Crisis: Developing More Sustainable Production and Consumption. London: Earthscan.

Elias, Norbert. 1978. The Civilizing Process, Volume 1: The History of Manners. Oxford: Basil Blackwell.

Evans, David, Hugh Campbell \& Anne Murcott (eds). (2013) Waste Matters: New Perspectives on Food and Society. Oxford: Wiley.

Fairlie, Simon. 2010. Meat: A Benign Extravagance. East Meon, Hampshire: Permanent 
Publications.

FAO. 2006. Livestock's Long Shadow: Environmental Issues and Options. Rome: Food and Agriculture Organization of the United Nations.

Fiddes, Nick. 1991. Meat: A Natural Symbol. London and New York: Routledge.

Fox, Nicols. 1997. Spoiled: The Dangerous Truth about a Food Chain Gone Haywire. New York: BasicBooks.

Freidberg, Susanne. 2009. Fresh: A Perishable History. Cambridge, MA: The Belknap Press of Harvard University Press.

Gewertz, Deborah \& Frederick Errington. 2010. Cheap Meat: Flap Food Nations in the Pacific Islands. Berkeley: University of California Press.

Goody, Jack. 1982. Cooking, Cuisine and Class: A Study in Comparative Sociology. Cambridge: Cambridge University Press.

Haraway, Donna. 2008. When Species Meet. Minneapolis: University of Minnesota Press. Harris, Marvin. 1998a [1985]. Meat Hunger. In Good to Eat: Riddles of Food and Culture. Long Grove, IL: Waveland Press.

Harris, Marvin. 1998b [1985]. Good to Eat: Riddles of Food and Culture. Long Grove, IL: Waveland Press.

Harrison, Ruth. 1964. Animal Machines. London: Vincent Stuart Publishers.

Heath, Deborah \& Anne Meneley (eds). 2007. In Focus: The Techne and Technoscience of Food and Drink. American Anthropologist 109(4).

Heath, Deborah \& Anne Meneley. 2010. The Naturecultures of Foie Gras: Techniques of the Body and a Contested Ethics of Care. Food, Culture and Society 13(3): 421-452.

Holtzman, Jon. 2009. Uncertain Tastes: Memory, Ambivalence, and the Politics of Eating in Samburu, Northern Kenya. Berkeley: University of California Press.

Horowitz, Roger. 2006. Putting Meat on the American Table: Taste, Technology, Transformation. Baltimore: The Johns Hopkins University Press. 
Hubert, Henri \& Marcel Mauss. 1964. Sacrifice: Its Nature and Functions, translated by W. D. Halls, London: Routledge \& Kegan Paul.

Hurn, Samantha. 2012. Humans and Other Animals: Human-Animal Interactions in CrossCultural Perspective. London: Pluto Press.

Janeja, Manpreet K. 2010. Transactions in Taste: The Collaborative Lives of Everyday Bengali Food. New Delhi: Routledge.

Kelly, Robert L. 1995. The Foraging Spectrum: Diversity in Hunter-Gatherer Lifeways. Washington, DC: Smithsonian Institution Press.

Kirksey, S. Eben \& Stefan Helmreich. 2010. The Emergence of Multispecies Ethnography. Cultural Anthropology 25(4): 545-576.

Klein, Jakob A. 2008. Afterword: Comparing Vegetarianisms. In Food: Memory, Pleasure and Politics, edited by Caroline Osella \& Filippo Osella. Special Issue of South Asia: Journal of South Asian Studies 31(1): 199-212.

Kleinman, Arthur \& James L. Watson (eds). 2006. SARS in China: Prelude to Pandemic? Stanford: Stanford University Press.

Latour, Bruno. 2005. Reassembling the Social: An Introduction to Actor-Network-Theory. Oxford: Oxford University Press.

Lawrence, Felicity. 2013. Horsemeat Scandal: Timeline. Ten Key Moments of Revelation in the Investigation. The Guardian, 10 May 2013. Available at: http://www.guardian.co.uk/uk/2013/may/10/horsemeat-scandal-timeline-investigation

Leach, Melissa \& Sarah Dry (eds). 2010. Epidemics: Science, Governance and Social Justice. London and New York: Earthscan.

Lee, Richard B. \& Irven DeVore (eds). 1968. Man the Hunter. Chicago: Aldine Publishing Company.

Leitch, Alison. 2003. Slow Food and the Politics of Pork Fat: Italian Food and European Identity. Ethnos 68(4): 437-462. 
McMichael, Philip. 2009. A Food Regime Genealogy, Journal of Peasant Studies 36(1): 139169.

Mennell, Stephen. 1985. All Manners of Food: Eating and Taste in England and France from the Middle Ages to the Present. Oxford: Blackwell.

Nestle, Marion. 2003. Safe Food: Bacteria, Biotechnology, and Bioterrorism. Berkeley: University of California Press.

Osella, Caroline \& Filippo Osella (eds). 2008. Food: Memory, Pleasure and Politics. Special Issue of South Asia: Journal of South Asian Studies 31(1).

Pachirat, Timothy. 2011. Every Twelve Seconds: Industrialized Slaughter and the Politics of Sight. New Haven: Yale University Press.

Paxson, Heather. 2008. Post-Pasteurian Cultures: The Microbiopolitics of Raw-Milk Cheese in the United States. Cultural Anthropology 23(1): 15-27.

Pickering, Andrew. 2005. Asian Eels and Global Warming: A Posthumanist Perspective on Society and the Environment. Ethics and the Environment 10(2): 29-43.

Popkin, Barry M. 1993. Nutritional Patterns and Transitions. Population and Development Review 19(1): 138-157.

Radcliffe-Brown, A. R. 1948. The Andaman Islanders. Glencoe: The Free Press.

Safran Foer, Jonathan. 2009. Eating Animals. New York: Little, Brown and Company.

Sahlins, Marshall. 1976. Culture and Practical Reason. Chicago: University of Chicago Press.

Sahlins, Marshall. 1993. Goodbye to Tristes Tropes: Ethnography in the Context of Modern World History. The Journal of Modern History 65(1): 1-25.

Schlosser, Eric. 2002. Fast Food Nation: What the All-American Meal is Doing to the World. London: Penguin Books.

Schneider, Mindi. 2011. Feeding China's Pigs: Implications for the Environment, China's Smallholder Farms and Food Security. Institute for Agriculture and Trade Policy. 
Available at: < http://www.iatp.org/files/2011_04_25_FeedingChinasPigs_0.pdf>

Sinclair, Upton. 1906. The Jungle. Doubleday, Page \& Company.

Smil, Vaclav. 2002. Eating Meat: Evolution, Patterns, and Consequences. Population and Development Review 28(4): 599-639.

Solomon, Harris. 2014. Taste Tests: Pizza and the Gastropolitical Laboratory in Mumbai. Ethnos 79(1): 19-40.

Stanford, Craig B. 2001. The Hunting Apes: Meat Eating and the Origins of Human Behavior. Princeton, NJ: Princeton University Press.

Striffler, Steve. 2005. Chicken: The Dangerous Transformation of America's Favorite Food. New Haven and London: Yale University Press.

Strong, Jeremy. 2006. The Modern Offal Eaters. Gastronomica 6(2): 30-39.

Sutton, David E. 2001. Remembrance of Repasts: An Anthropology of Food and Memory. Oxford and New York: Berg.

Sutton, David E. 2010. Food and the Senses. Annual Review of Anthropology 39: 209-223.

Tambiah, Stanley J. 1969. Animals are Good to Think and Good to Prohibit. Ethnology 8(4): 423-459.

Tracey, Megan. 2013. Pasteurizing China's Grasslands and Sealing in Terroir. American Anthropologist 115(3): 437-452.

Valeri, Valerio. 1992. If We Feed Them, We Do not Feed on Them: A Principle of Huaulu Taboo and its Application, Ethnos 57(3-4): 149-167.

Valeri, Valerio. 2000. The Forest of Taboos: Morality, Hunting, and Identity Among the Huaulu of the Moluccas. Madison: University of Wisconsin Press.

Vialles, Noëlie, 1994. Animal to Edible, translated by J.A. Underwood. Cambridge: Cambridge University Press.

Watson, James L. 2014. Meat: A Cultural Biography in (South) China. In Food Consumption in Global Perspective: Essays in the Anthropology of Food in Honour of Jack Goody, 
edited by Jakob A. Klein \& Anne Murcott, pp.25-44. New York: Palgrave Macmillan.

Weiss, Brad. 2011. Making Pigs Local: Discerning the Sensory Character of Place. Cultural Anthropology 26(3): 438-461.

Wilk, Richard. 2006. From Wild Weeds to Artisanal Foods. In Fast Food/Slow Food: The Cultural Economy of the Global Food System, edited by Richard Wilk, pp. 13-27. Lanham, MD: Altamira Press.

Wrangham, Richard. 2009. Catching Fire: How Cooking Made Us Human. London: Profile Books.

Yates-Doerr, Emily. 2012. Meeting the Demand for Meat? Anthropology Today 28(1): 11-15.

Yates-Doerr, Emily \& Annemarie Mol. 2012. Cuts of Meat: Disentangling Western Natures-Cultures. Cambridge Anthropology 30(2): 48-64. 